\title{
INVESTMENT PRIORITIZING IN HIGH TECH INDUSTRIES BASED ON SWARA-COPRAS APPROACH
}

\author{
Sarfaraz HASHEMKHANI ZOLFANI ${ }^{\mathrm{a}, \mathrm{b}}$, Mohsen BAHRAMI ${ }^{\mathrm{a}, \mathrm{b}}$ \\ ${ }^{a}$ Technology Foresight Group, Department of Management, Science and Technology, \\ Amirkabir University of Technology (Tehran Polytechnic), P.O. Box 1585-4413, Tehran, Iran \\ ${ }^{\mathrm{b}}$ Futures Studies Research Institute, Amirkabir University of Technology (Tehran Polytechnic), \\ P.O. Box 1585-4413, Tehran, Iran
}

Received 28 February 2013; accepted 24 November 2013

\begin{abstract}
One of the symbols of developed countries is high tech industries. High tech industries have a large margin. One of the priorities of developing countries is the progress in this type of industries. The decisions about priority of developing an industry are so hard that seems it should be seen from different perspectives. This research is focused on decision and policy making in priority of high tech industries in Iran. Two MCDM methods are applied in this research for decision making in this area. SWARA for evaluating and weighting criteria and COPRAS for evaluating and ranking alternatives are applied. Eleven experts from different fields participated in this research to make decision with SWARA and COPRAS. Four high tech industries including Biomedical Micro Electromechanical Systems (BioMEMS), Nano Technology, Biotechnology, and Biomedical Engineering were selected for this research. These industries were selected based on the potential of Iran. Final result shows that Nanotechnology is at the top of priorities in Iran. Authors believe that this methodology can be useful in other issues in this and other areas of research.
\end{abstract}

Keywords: investment, high tech industry, multi criteria decision making (MCDM), SWARA, COPRAS.

JEL Classification: C44, C51, L52.

\section{Introduction}

Emerging economies must reinforce their capabilities for investigation so that they can move along with the advanced countries' economies (Tsai et al. 2009). In the long time, indeed, economic performance of a country requires to provide, adjust, and link an innovative

Corresponding author Sarfaraz Hashemkhani Zolfani

E-mail:sa.hashemkhani@gmail.com 
capacity (Ernst 2005; Ernst, Naughton 2005; Tsai et al. 2009). In the Islamic Republic of Iran (a developing country) with a population of over 71 million and area of $1,648,195 \mathrm{~km}^{2}$ in the center of the Middle East, there are over three million university students, of which $65 \%$ are women. Almost 35\% of the populations are working in the public and private sectors (Ghazinoory, Huisingh 2006; Ghazinoory, Farazkish 2010). Although Iran's economy largely is governed by the government, affiliated companies, or public entities, private sector have a share of $30-40 \%$. There are main active industries in Iran which play significant roles in the export area. Some of them are oil, petrochemicals, steel, food and agriculture industries. The $20 \%$ share of industry in Iran's gross domestic product is lower than in most industrialized countries. The rest includes $25 \%$ agriculture, $16 \%$ oil (average of the past 20 years), as well as the share the service sector. Oil exports provide the $80 \%$ of the export income and $50 \%$ of the public budget (Ghazinoory 2005; Ghazinoory, Farazkish 2010). As a top priority, improving the scientific and technological developments is the main focus of the Iranian policy-makers in order to accelerate emerging technologies and developing high tech industries in particular (Ghazinoory, Ghazinoori 2006). Policy making in high tech industry is one priority of Iranian policy makers and the government, but investment in industries is enormous for the government. Identifying potential of each work in the country is in the top of priority. Literature of investment is especially important in this area. Social risk, policy risk, economical risk, credit risk, technological risk, interest rate risk and operating risk (Kent 1992; Better et al. 2008; Gao et al. 2008; Li, Ma 2008; Peng et al. 2009, 2010; Shen 2009; Liaudanskienè et al. 2010), contract's risks (Zavadskas et al. 2010; Boguslauskas et al. 2011; Wu et al. 2012) are among risks for selecting the kind of investment. The decision making process can be divided into four components from an investor's viewpoint: problem recognition, information search, evaluation of alternatives, and investment decision (Shyng et al. 2010; Keršulienè, Turskis 2011). So many research has been done in order to make the optimal investment decision as well as to assess its strategies and risks (Metrick 1999; Bayraktar, Young 2010; Ba et al. 2011; Wu et al. 2012). This research is focused on priority of investment in high tech industries in Iran. Based on current potential of Iran, four industries were selected at the top of high tech industries including: Biomedical Micro Electromechanical Systems (BioMEMS), Nano Technology, Biotechnology and Biomedical engineering. Prioritizing high tech industries is a Multi Criteria Decision Making (MCDM) issue and is at the top level of decision making process. For this aim, SWARA and COPRAS methods were applied as approaches to solve this problem. SWARA is a new powerful method in MCDM that has an advantage in policy making. COPRAS method is considered for evaluating alternatives of research.

The process of this research is shown in Fig. 1.

\section{High tech industries}

According to the fifth development plan of Islamic republic of Iran, Iran should move toward a leadership strategy in the Middle East zone. The Fifth development plan illustrated that Iran aims to play the key role in the technology in this zone. Iran has started to develop strategies 


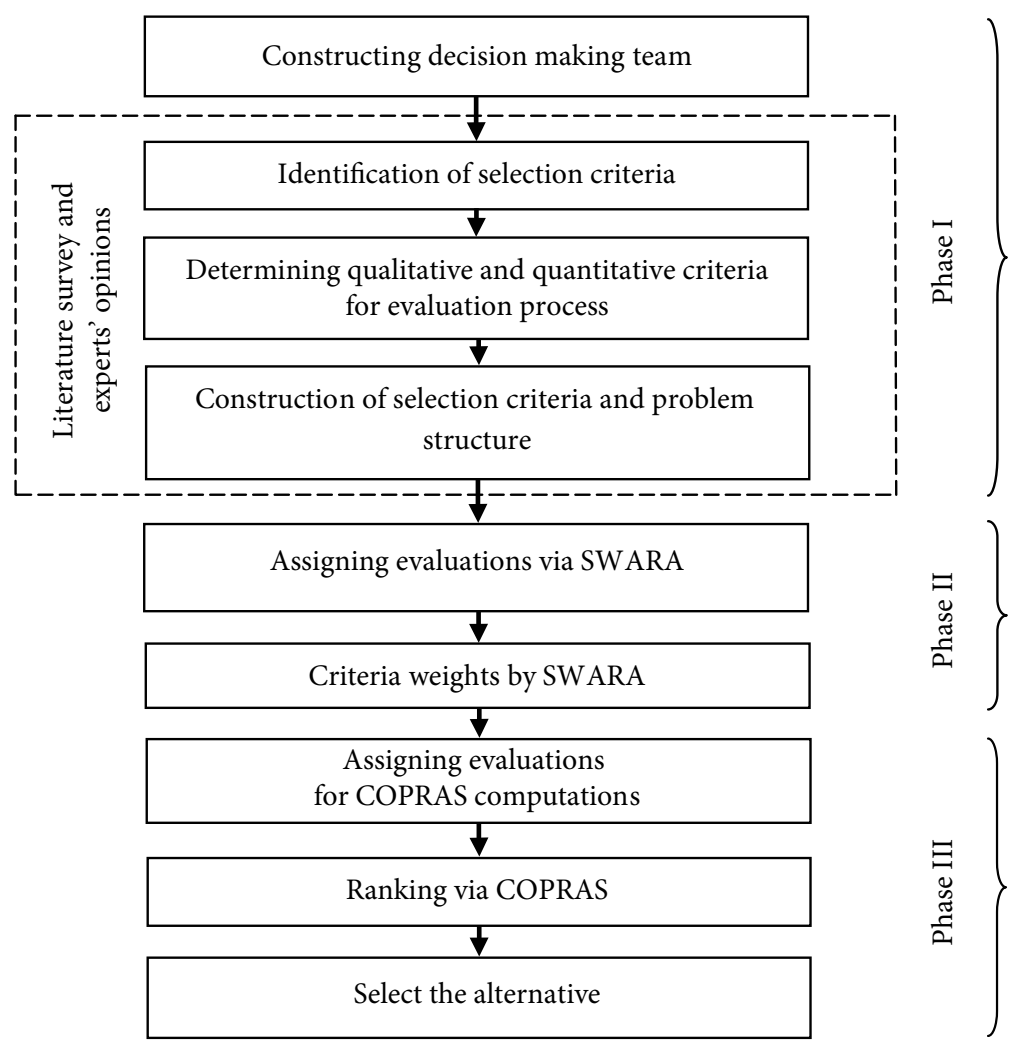

Fig. 1. The evaluation procedure of the proposed research

in high tech industries. Four important industries for Iranian government and policy makers are Biomedical Micro Electromechanical Systems, Nano Technology, Biotechnology and Biomedical Engineering. Iran seeks to play an important role in these industries but investment in these industries is so enormous. It's logical to prioritize them based on their preference.

\subsection{Biomedical micro electromechanical systems (BioMEMS) $\left(A_{1}\right)$}

From the early 1970s, when micro-electro-mechanical systems were invented by now, the biomedical applications of these miniature systems have been considered so important (Petersen 1982; Wise, Najafi 1991). Today, Biomedical or Biological Micro-Electro-Mechanical Systems (BioMEMS) are the significant subjects of investigation and have a wide range key biomedical application (Ferrari 2004). One can define generally the BioMEMS "devices or systems, constructed using techniques inspired from micro/nano-scale fabrication, that are used for processing, delivery, manipulation, analysis, or construction of biological and chemical entities" which include all interfaces life sciences and biomedical disciplines with micro and nano scale systems (Bashir 2004). 


\subsection{Nano technology $\left(A_{2}\right)$}

A broad array of techniques for manipulating matter at the scale of nano-sized particles able to change their (normal) physical (mechanical, optical, magnetic, electronic or chemical) properties and behaviour, manifesting new and surprising modes of matter is defined as Nano Technology. Physics, chemistry, material sciences, biotechnology and medicine nanotechnology as the bridging disciplines envision innovative, even revolutionary benefits, creations such as ultra-strong materials, self-cleaning surfaces, high-efficient energy provisioning, and 'intelligent' drugs that can treat patients at cell level (Boholm 2011). Meanwhile, as one of the high technologies, Nano Technology refers to the field of applied science and technology that govern the atomic and molecular scale subjects, generally 100 nanometers or smaller, and the fabrication of devices or materials that lie within that size range (Naschie 2006). Different kinds of the consumer products including cosmetics, cleaning agents, dental care products, electronic components, textiles, paint, coatings, sporting gear, food additives and food packing material, hygiene products, and medicine already were the commercial applications (Boholm 2011). The convergence of the nano technology with other fields, especially biotechnology, information technology, and new technologies is based on cognitive science and results in much of its impact. Thus, the fact is that occurring most of nanotechnology affecting mechanisms through other technologies is natural. Consequently, not all the people in a society will realize the real source of changes (Ghazinoory, Ghazinouri 2009). The question about what differences these will have with other high technologies, such as information technology or biotechnology, has been the main concern in the field of far-ranging claims that have been made about potential applications of nanotechnology (Staggers et al. 2008). Nanotechnology, on the one hand, is drawn from some fields such as applied physics, material science, interface and colloidal science, device physics, supra molecular chemistry, self-replicating machines and robotics, chemical engineering, mechanical engineering, biological engineering, and electrical engineering, as a highly multidisciplinary field. On the other hand, other high technologies focus on the limited fields of science and technology (Ghazinoory, Farazkish 2010).

\subsection{Biotechnology $\left(A_{3}\right)$}

It is largely considered that Life sciences and biotechnology as one of the most promising advanced technologies for near future are enabling technologies like information technology, applying for many private and public benefits purposes. Regarding the recent scientific developments, the knowledge explosion on living systems brings so many new applications. New and innovative approaches to healthcare are certainly required to respond the ageing populations and poor countries needs. Because either some of disease factors have become resistant to the existing cures like antibiotics, or there is no cure for some diseases at all. However, biotechnology helps the increasing number of medical services and drugs are produced safer, more ethical, and less expensive (e.g. human growth hormone without risk of Creutzfeldt-Jakob disease, treatment for hemophiliacs with unlimited sources of coagulation factors free from AIDS and hepatitis $C$ virus, human insulin, and vaccines against hepatitis $\mathrm{B}$ and rabies) (European Commission 2002). 


\subsection{Biomedical engineering $\left(A_{4}\right)$}

For some reasons, such as lowering the birth rate and aging population in the most countries of the world, $21^{\text {st }}$ century is known as the "human" century. China and India are among those countries with large populations that experience aging during the second half of the century. Thus, the development of medical care, health, and welfare technologies is essential. Both expectations for the creation of new medical technologies stemming from trends in development and practical application of the life, and for the development of medical technologies arising from needs of the global economy are increasing over the time (Kikuchi 2007). The concept of patient monitoring within clinical medicine is a new concept that needs the development of biomedical instrumentation technology to measure the physical and chemical information and signals emitted by the living body in a minimally (or non-) invasive and continuous manner. Therefore, it plays a key role to "enhancement of the quality of medical care". Similarly, the one dimensional measurements of some technology (e.g. medical imaging) have been developed into two- and sometimes three-dimensional measurements and their development is faster than before (Kikuchi 2007).

\section{The criteria for selecting high tech industries}

There are many factors that can affect policy making for investment in high tech industries. There are not many published research in this area, so more works are necessary. Considering Iran needs, there are some important criteria that we present in this section. The model of research is shown in Table 1.

Table 1. The model of research

\begin{tabular}{|c|c|c|}
\hline Criteria & & Reference \\
\hline Technological factors & $\operatorname{Max}$ & $\begin{array}{l}\mathrm{C}_{1} \text { Mäkipelto, Takala 2009; Mäkipelto 2010b; Mendonca 2009; } \\
\text { Harbi et al. 2009; Athreye, Keeble 2000; Tsai 2004; } \\
\text { Praset 1998; Zhang et al. } 2013\end{array}$ \\
\hline Economic factors & Min & $\begin{array}{l}\mathrm{C}_{2} \text { Mäkipelto, Takala 2009; Mäkipelto 2010b; Chorev, } \\
\text { Anderson 2006; Rosa et al. } 2011\end{array}$ \\
\hline $\begin{array}{l}\text { Political and legislative } \\
\text { factors }\end{array}$ & $\operatorname{Max}$ & $\begin{array}{l}\mathrm{C}_{3} \text { Mäkipelto, Takala 2009; Mäkipelto 2010b; Liu 1993; } \\
\text { Wang 2010; Temouri et al. 2010; Hemmert 2004; Godin } \\
\text { 2004; Ouyang 2006; Kenney et al. 2013; Mamuneas 1999; } \\
\text { Lai 2010; Alvarez, Marin } 2013\end{array}$ \\
\hline Total costs of investment & Min & $\begin{array}{l}\mathrm{C}_{4} \text { Mäkipelto 2009, 2010a; Bor et al. 2010; Hu, Quan 2005; } \\
\text { Dulluri, Raghavan 2008; Wu, Chen 2006; } \\
\text { Benou, Madura } 2005\end{array}$ \\
\hline $\begin{array}{l}\text { Social (personnel) } \\
\text { factors }\end{array}$ & $\operatorname{Max}$ & $\begin{array}{ll}\mathrm{C}_{5} \text { Mäkipelto, Takala 2009; Mäkipelto 2010b; Lin et al. 2006; } \\
\text { Kulviwat et al. 2009; Seo 2013; Baron, Markman 2003; } \\
\text { Law, Gunasekaran 2012; Tzafrir, Eitam-Meilik } 2005\end{array}$ \\
\hline Suppliers & $\operatorname{Max}$ & $\begin{array}{l}\mathrm{C}_{6} \text { Mäkipelto 2009, 2010a; Ruyter et al. 2001; } \\
\text { Chung et al. 2011; Hurmelinna et al. 2002; Lee et al. 2009a; } \\
\text { Lee et al. 2009b }\end{array}$ \\
\hline $\begin{array}{l}\text { Ecological } \\
\text { (environmental) factors }\end{array}$ & $\operatorname{Max}$ & $\begin{array}{l}\mathrm{C}_{7} \text { Mäkipelto, Takala 2009; Mäkipelto 2010b; Chu et al. 2009; } \\
\text { Rosa et al. } 2011\end{array}$ \\
\hline
\end{tabular}




\subsection{Technological factors}

The techno-economic features of the investment mode are defined by the technological factors that set some restrictions on the usability. They include the environment-friendly production mode, new high-efficiency technology, production mode that increases flexible production mode.

\subsection{Economical factors}

The life cycle profits of production investments are affected monetarily by the economical factors such as low operation and maintenance costs, the predictability of the market price, compatibility of the investments with investors' production portfolio, low investment costs, and long-term tax/support policy.

\subsection{Political and legislative factors}

The investment process with direct or indirect regulation is affected by the political and legislative factors such as the long-term acceptance of investments, equal rights of the different actors, the long-term permission policy, the predictability of the market price, the long-term tax/support policy.

\subsection{Total cost of investment}

Total cost of investment includes low investment cost, short term of delivery and appraisable operation and management cost.

\subsection{Social (personnel) factors}

The share of personnel costs of the life cycle profits of the investment is defined by the social (personnel) factors such as the stability of personnel, the flexibility of personnel, the availability of skillful personnel, and low personnel costs.

\subsection{Suppliers}

Suppliers have key roles in industries. Accessibility, ability in R\&D researches, potential in creativity and total cost are important issues in this section.

\subsection{Ecological (environmental) factors}

The level of environmental friendliness of the investments is described by these factors. The existing needs have to be fulfilled and connected to the environmental needs.

\section{Methodology}

SWARA method is a new methodology that is suitable in policy making. Decision making at the top level of government is higher than general decision making. SWARA has more concentration on experts' ideas and authors believe that this methodology is the best choice 
for applying in this research. COPRAS is also a known method in ranking and prioritizing alternatives. This novel hybrid methodology is considered for this research.

\subsection{Step-wise weight assessment ratio analysis (SWARA) method}

Weight assessment is an important issue in many MADM problems. Some famous weight assessment approaches in the literature including analytic hierarchy process (AHP) (Saaty 1980), analytic network process (ANP) (Saaty, Vargas 2001), Entropy (Shannon 1948; Susinskas et al. 2011; Keršulienė, Turskis 2011), FARE (Ginevicius 2011), SWARA (Keršulienè et al. 2010), etc. Among these methods, SWARA method is one of the brand-new ones.

In this method, an expert has an important role on evaluations and calculating weights. Also, each expert chooses the importance of each criterion. Next, each expert ranks all the criteria from the first to the last one. An expert uses his or her own implicit knowledge, information and experiences. Based on this method, the most significant criterion is given rank 1 , and the least significant criterion is given rank last. The overall ranks to the group of experts are determined according to the mediocre value of ranks (Keršuliene, Turskis 2011).

The ability to estimate experts' opinion about importance ratio of the criteria in the process of their weights determination is the main element of this method (Keršulienè et al. 2010). Moreover, this method is helpful for coordinating and gathering data from experts. Furthermore, SWARA method is uncomplicated and experts can easily work together. The main advantage of this method in decision making is that in some problems priorities are defined, based on policies of companies or countries, and there aren't any needs for evaluation to rank criteria.

In other methods like AHP or ANP, our model is created based on criteria, and experts' evaluations will affect priorities and ranks. So, SWARA can be useful for some issues that priorities are known according to former situations, and finally, SWARA proposed for applying in certain environment of decision making. All developments of decision making models based on SWARA method up to now are listed below:

- Hashemkhani Zolfani and Zavadskas (2013) Sustainable Development of Rural Areas' Building Structures Based on Local Climate;

- Hashemkhani Zolfani et al. (2013a) in design of products;

- Hashemkhani Zolfani et al. (2013b) in selecting the optimal alternative of mechanical longitudinal ventilation of tunnel pollutants;

- Zolfani et al. (2013) Investigating on the success factors of online games based on explorer;

- Hashemkhani et al. (2013c) in decision making on business issues with foresight perspective;

- Aghadie et al. (2013a) in machine tool selection.

The procedure for the criteria weights determination is presented in Fig. 2.

\subsection{COPRAS (Complex Proportional Assessment) method}

In order to evaluate the overall efficiency of an alternative, it is essential to identify the most important criteria, to evaluate alternatives and assess information with respect to these 


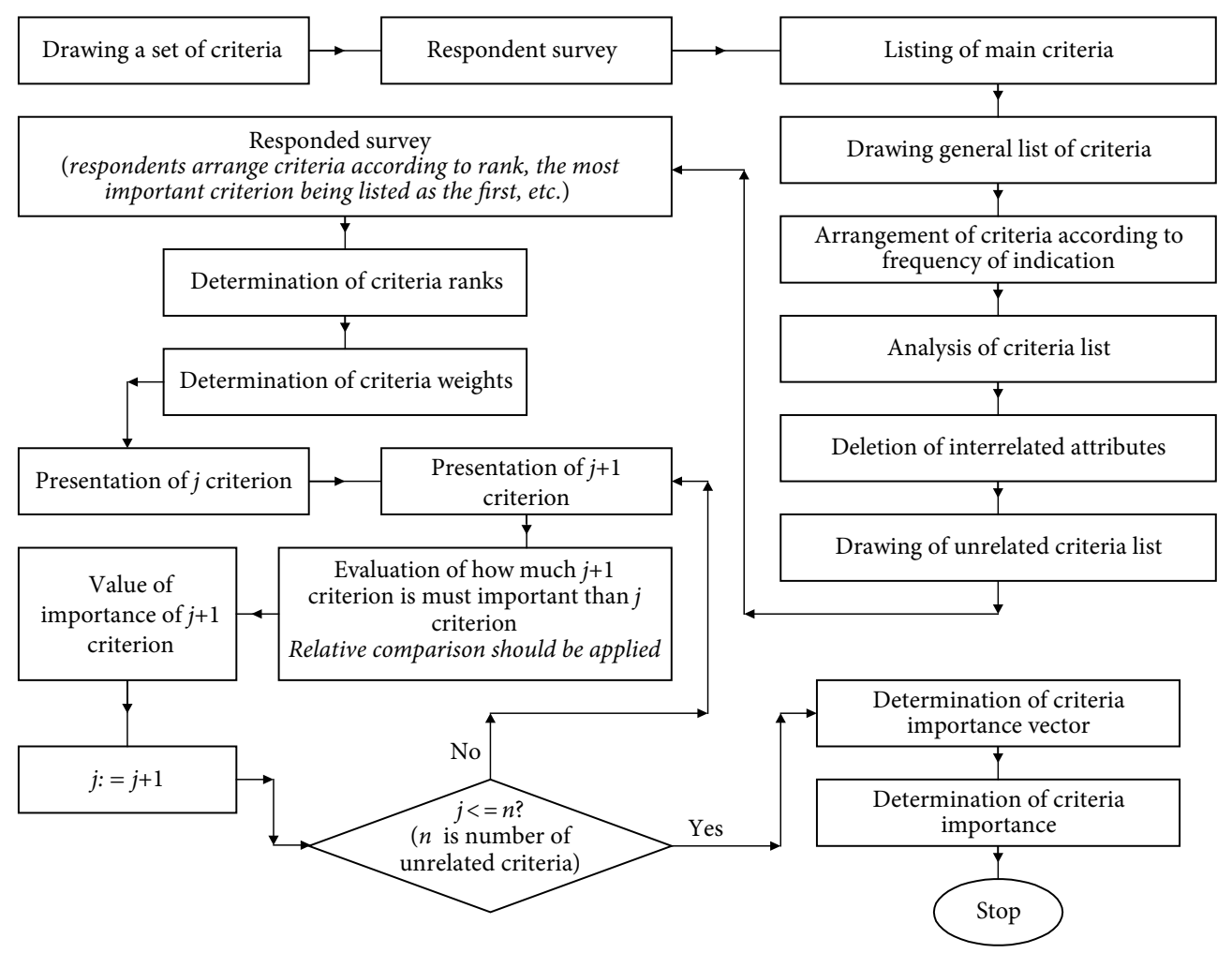

Fig. 2. Determining of the criteria weights based on Keršuliene, Turskis (2011)

criteria; develop methods for evaluating the criteria to meet the DMs' needs. Decision analysis is concerned with the situation in which a DM has to choose among several alternatives by considering a particular set of usually conflicting criteria. For this reason Complex Proportional Assessment (COPRAS) method which was developed by Zavadskas and Kaklauskas (1996) can be applied. In real situations, the most of the criterion for evaluating alternatives deals with vague feature, and values of criteria cannot be expressed with exact numbers.

The recent developments of decision making models based on COPRAS method are listed below:

- Zolfani et al. (2011) in forest roads locating;

- Hashemkhani Zolfani et al. (2012a) in supplier selection;

- Hashemkhani Zolfani et al. (2012b) in quality control manager selection;

- Aghdaie et al. (2012) prioritizing projects of municipality;

- Bitarafan et al. (2012) evaluating the construction methods of cold-formed steel structures in reconstructing the areas damaged in natural crises;

- Fouladgar et al. (2012) maintenance strategy selection;

- Rezaeiniya et al. (2012) in greenhouse locating;

- Aghdaie et al. (2013b) market segment evaluation and selection. 
The procedure of applying the COPRAS method consists in the following steps:

1. Selecting the set of the most important criteria, describing the alternatives;

2. Constructing the decision-making matrix $X$ :

$$
X=\left[\begin{array}{cccc}
x_{11} & x_{12} & \ldots & x_{1 m} \\
x_{21} & x_{22} & \ldots & x_{2 m} \\
\vdots & \vdots & \ddots & \vdots \\
x_{n 1} & x_{n 2} & \ldots & x_{n m}
\end{array}\right] ; i=\overline{1, n} \text { and } j=\overline{1, m}
$$

where: attribute $j$ is in the alternative $i$ of a solution; $m$ is the number of attributes; $n$ is the number of the alternatives compared;

3. Determining significances of the criteria $q_{i}$;

4. Normalizing the decision-making matrix $\bar{X}$. The normalized values of this matrix are calculated as:

$$
\bar{x}_{i j}=\frac{x_{i j}}{\sum_{j=1}^{n} x_{i j}} ; i=\overline{1, n} \text { and } j=\overline{1, m} \text {. }
$$

After this step we have normalized decision making matrix:

$$
\bar{X}=\left[\begin{array}{llll}
\bar{x}_{11} & \bar{x}_{12} & \cdots & \bar{x}_{1 m} \\
\bar{x}_{12} & \bar{x}_{12} & \cdots & \bar{x}_{2 m} \\
\cdots & \cdots & \ddots & \cdots \\
\bar{x}_{n 1} & \bar{x}_{n 1} & \cdots & \bar{x}_{n m}
\end{array}\right]
$$

5. Calculating the weighted normalized decision matrix $X$. The weighted normalized values $\hat{X}_{i j}$ are calculated as follows:

$$
\hat{x}_{i j}=\bar{x}_{i j} \cdot q_{j} ; i=\overline{1, n} \text { and } j=\overline{1, m}
$$

where: $q_{i}$ is the significance of the $i$ th criterion. Then, the normalized decision-making matrix is:

$$
\hat{X}=\left[\begin{array}{llll}
\wedge & \wedge & & \hat{x}_{11} \\
\hat{x} & x_{11} & \ldots & x_{11} \\
\hat{x}_{11} & x_{11} & \ldots & \hat{x}_{11} \\
\vdots & \vdots & \ddots & \vdots \\
\wedge & \wedge & & \wedge \\
x_{11} & x_{11} & \ldots & x_{11}
\end{array}\right] ; i=\overline{1, n} \text { and } j=\overline{1, m}
$$

6. Calculating the sums $P_{i}$ of criterion values, whose larger values are more preferable:

$$
P_{i}=\sum_{j=1}^{k} \hat{x_{i j}}
$$

7. Calculating the sums $R_{i}$ of criterion values, whose smaller values are more preferable:

$$
R_{i}=\sum_{j=k+1}^{m} \hat{x}_{j}
$$

In Eq. (7) $(m-k)$ is the number of criteria which must be minimized. 
8. Determining the minimal value of $R_{i}$ as follows:

$$
R_{\min }=\min _{i} R_{i} ; i=\overline{1, n} \text {; }
$$

9. Calculating the relative significance of each alternatively $Q_{i}$ the expression:

$$
Q_{i}=P_{i}+\frac{R_{\min } \sum_{i=1}^{n} R_{i}}{R_{i} \sum_{i=1}^{n} \frac{R_{\min }}{R_{i}}} ;
$$

10. Determining the optimally criterion by $K$ the formula:

$$
K=\max _{i} Q_{i} ; i=\overline{1, n} \text {; }
$$

11. Determining the priority order of the alternatives;

12. Calculating the utility degree of each alternative by the formula:

$$
N_{i}=\frac{Q_{i}}{Q_{\max }} \times 100 \%
$$

Here $Q_{i}$ and $Q_{\max }$ are the significances of the alternatives obtained from Eq. (9).

\section{Case study}

The current study focuses on Iran situation in industries. The case study in Iran can be a suitable case for other research like this. Appropriate choice has a key role in the future of a nation. Developing countries positioned in critical position, policy and decision making in these countries can make a good vision for future but derivative decision can destroy dreams of a nation.

This part consists of three steps. At the first step, information about experts will be presented, because experts are the core of this policy and decision making. At the second step, the results of SWARA method will be presented, and finally at the last step, the results of COPRAS method will be presented.

\subsection{Introducing experts}

As mentioned in introduction, four industries that are acceptable in Iran, were selected for this comparison and research. In this study, experts were participating in SWARA and COPRAS methods. As we know MCDM methods are based on experts' ideas. The information about experts is shown in Table 2.

\subsection{SWARA results}

In this section, SWARA is applied for evaluating the model of research that presented in Table 1. Weights and relative importance of each criterion will be calculated in this section. Experts' ideas gathered and its results are shown in Table 3. 
Table 2. Background information of experts

\begin{tabular}{ccc}
\hline Category & Classification & No. \\
\hline \multirow{4}{*}{ Working background } & Engineering & 2 \\
\cline { 2 - 3 } & Social sciences & 1 \\
\cline { 2 - 3 } & Industries managers & 2 \\
\cline { 2 - 3 } & Political sciences & 1 \\
\cline { 2 - 3 } & Government managers & 3 \\
\cline { 2 - 3 } Education level & Economic & 2 \\
\cline { 2 - 3 } & Bachelor & 0 \\
\cline { 2 - 3 } & Master & 6 \\
\hline \multirow{2}{*}{ Sex } & PhD & 5 \\
\cline { 2 - 3 } & Male & 9 \\
\hline
\end{tabular}

Table 3. Final results of SWARA method in weighting criteria

\begin{tabular}{ccccc}
\hline Criterion & $\begin{array}{c}\text { Comparative } \\
\text { importance of } \\
\text { average value } s_{j}\end{array}$ & $\begin{array}{c}\text { Coefficient } \\
k_{j}=s_{j}+1\end{array}$ & $\begin{array}{c}\text { Recalculated weight } \\
w_{j}=\frac{x_{j-1}}{k_{j}}\end{array}$ & $\begin{array}{c}\text { Weight } \\
q_{j}=\frac{w_{j}}{\sum w_{j}}\end{array}$ \\
\hline$X_{2}$ & & 1 & 1 & 0.238 \\
\hline$X_{3}$ & 0.177 & 1.177 & 0.849 & 0.202 \\
\hline$X_{5}$ & 0.223 & 1.223 & 0.649 & 0.154 \\
\hline$X_{4}$ & 0.236 & 1.236 & 0.525 & 0.124 \\
\hline$X_{1}$ & 0.136 & 1.136 & 0.462 & 0.110 \\
\hline$X_{7}$ & 0.191 & 1.191 & 0.387 & 0.092 \\
\hline$X_{6}$ & 0.132 & 1.132 & 0.341 & 0.080 \\
\hline$\sum$ & & & 4.213 & \\
\hline
\end{tabular}

${ }^{*} s_{j}$ is calculated based on average of expert's ideas. The information gained privately from each expert and the scale is based multiples of five percent. The impotance of each criterion is calculated based on relative importance of higher criterion. Videlicet, 0.177 shows relative difference of $X_{3}$ and $X_{2} .0 .177$ is calculated based on experts' ideas and for illustrating $s_{i}$ all 11 ideas are presented here. Eleven ideas are includes: $0.2,0.15,0.3,0.25$, $0.05,0.2,0.1,0.15,0.2,0.25,0.1$ and the average of them is 0.177 . For other criteria the process are as the same.

Priority, weights and relative importance of each criterion is calculated with SWARA and economical factors are at the top of priority. Results of this step will be used in COPRAS method for evaluating alternatives.

\subsection{COPRAS results}

After determining all weights of every criterion and sub-criterion by SWARA method, COPRAS method was applied to evaluate and select four alternatives of high tech industries. At this stage of the application, the group of experts evaluated each alternative according to each criterion and Table 4 was developed. 
Table 4. Initial decision-making matrix with values of the attributes describing the compared alternatives (COPRAS)

\begin{tabular}{cccccccc}
\hline & $\mathrm{C}_{1}$ & $\mathrm{C}_{2}$ & $\mathrm{C}_{3}$ & $\mathrm{C}_{4}$ & $\mathrm{C}_{5}$ & $\mathrm{C}_{6}$ & $\mathrm{C}_{7}$ \\
\hline Opt & Max & Min & Max & Min & Max & Max & Max \\
\hline Weights & 0.238 & 0.202 & 0.154 & 0.124 & 0.110 & 0.092 & 0.080 \\
\hline$A_{1}$ & 6 & 5 & 7 & 4 & 7 & 6 & 6 \\
\hline$A_{2}$ & 7 & 4 & 7 & 4 & 6 & 6 & 7 \\
\hline$A_{3}$ & 6 & 4 & 7 & 3 & 6 & 6 & 7 \\
\hline$A_{4}$ & 5 & 5 & 7 & 4 & 7 & 6 & 6 \\
\hline$\sum$ & 24 & 18 & 28 & 15 & 26 & 24 & 26 \\
\hline
\end{tabular}

Besides, Table 4 indicates initial decision making matrix with the criteria values. For the weight $q_{i}$ of criteria, we used the weights in Table 3 . As mentioned before, the aim of using SWARA is to determine important weights of criteria that will be employed in COPRAS method.

Table 5. Weighted normalized matrix

\begin{tabular}{lccccccc}
\hline & $\mathrm{C}_{1}$ & $\mathrm{C}_{2}$ & $\mathrm{C}_{3}$ & $\mathrm{C}_{4}$ & $\mathrm{C}_{5}$ & $\mathrm{C}_{6}$ & $\mathrm{C}_{7}$ \\
\hline Opt & Max & Min & Max & Min & Max & Max & Max \\
\hline$A_{1}$ & 0.0595 & 0.0561 & 0.0385 & 0.0330 & 0.0296 & 0.023 & 0.0184 \\
\hline$A_{2}$ & 0.0694 & 0.0448 & 0.0385 & 0.0330 & 0.0253 & 0.023 & 0.0215 \\
\hline$A_{3}$ & 0.0595 & 0.0448 & 0.0385 & 0.0248 & 0.0253 & 0.023 & 0.0215 \\
\hline$A_{4}$ & 0.0495 & 0.0561 & 0.0385 & 0.0330 & 0.0296 & 0.023 & 0.0184 \\
\hline
\end{tabular}

The initial decision making matrix, has been normalized first, as discussed in previous section. The weighted normalized decision making matrix is presented in Table 5. According to results of Table 6 which shows evaluation of utility degree: $\boldsymbol{A}_{2}>\boldsymbol{A}_{3}>\boldsymbol{A}_{1}>\boldsymbol{A}_{4}$.

Table 6. Final results and ranking

\begin{tabular}{ccccc}
\hline$P$ & $R$ & $Q$ & $N$ & Ranking \\
\hline 0.169 & 0.0891 & 0.2424 & $92.55 \%$ & 3 \\
\hline 0.1777 & 0.0778 & 0.2619 & $100 \%$ & 1 \\
\hline 0.1647 & 0.0696 & 0.2587 & $98.77 \%$ & 2 \\
\hline 0.159 & 0.0891 & 0.2324 & $88.73 \%$ & 4 \\
\hline$R_{\min }$ & 0.0696 & & & \\
\hline
\end{tabular}

Due to the last column of Table $6, \boldsymbol{A}_{2}$ is defined as the best alternative in high tech industries investments.

\section{Methodological tips}

The important point that should be considered in this article, is the application of SWARA method in decision and policy making in top level of decision making and planning. In this 
research SWARA method was applied instead of other common methods like AHP and ANP because of general perspective of this method. SWARA framework is totally based on experts and policy makers that make decisions in top levels of organizations, industries and nations. The main idea of this research is at nation perspective and using SWARA method can be reasonable. COPRAS also is a powerful method for evaluating and ranking alternatives in all levels of decision making. COPRAS application is simple and very applicable. This methodology was applied in many research in new century. COPRAS is also known as the one of the best methods in Multi Criteria Decision Making (MCDM) field.

\section{Conclusions}

Decision and policy making about national issues is on the top of priority in each country. All programs aim at making a better future, and future can be better than now, if we have appropriate plans for it. All industries are useful and important for nations, but high tech industries are the symbol of developed countries. Developing countries like Iran have plans intended to join developed countries in near future. Iran is a developing country that has a long term planning to join to the developed countries. This research is conducted and structured regarding the fifth development plan of the Islamic Republic of Iran.

Prioritizing industries are very important for the development, and this research focuses on this issue. The process of decision making has a MCDM perspective. Authors believe that MCDM methods can be helpful in this area. Authors proposed two MCDM methods for this research which are SWARA and COPRAS. SWARA is a new and powerful in MCDM that can be useful in policy making issues and is used in this research for prioritizing and weighting criteria.

In this research, eleven experts from different fields participated to solve the problems of SWARA and COPRAS methods. Seven important criteria were selected from literature reviews of this area of research and prioritized after solving SWARA are Economical factors, Political and legislative factors, Social (Personnel) factors, Total costs of investment, Technological factors, Ecological (Environmental) factors and suppliers. In this research, four high tech industries were selected as well, in which Iran has a good potential. Results of COPRAS method show that Nano Technology is the best high tech industry to develop in Iran, after that Biotechnology is at the second place of importance, BioMEMS is the next, and Biomedical engineering is the last priority.

The general scheme of industries is still depending on government in Iran. The result of this research is useful for policies of government, and also private sectors are active in this area. The government should consider playing the important role in this area, therefore, high tech industries can develop with more speed and quality in Iran. It is obvious that this advantage of infrastructures and essential knowledge are present in Iran, and the chance exists that Iran can be one of the best countries in high tech industries in future.

This new hybrid MCDM method can be useful in other similar worldwide research. The authors proposed that this methodology can be helpful in other decision making issues from other areas. 


\section{Suggestions of future studies}

The authors suggest these matters for future researches as follows:

- Applying this methodology in other places in other countries and comparing the results of the new research with this research;

- Comparing this methodology with other methodologies for investments that presented before in a review article;

- Sensitivity analysis of experts' ideas in SWARA method.

\section{Reference}

Aghdaie, M. H.; Hashemkhani Zolfani, S.; Zavadskas, E. K. 2013a. Decision making in machine tool selection: an integrated approach with SWARA and COPRAS-G methods, Inzinerine Ekonomika Engineering Economics 24(1): 5-17.

Aghdaie, M. H.; Hashemkhani Zolfani, S.; Zavadskas, E. K. 2013b. Market segment evaluation and selection based on application of Fuzzy AHP and COPRAS-G methods, Journal of Business Economics and Management 14(1): 213-233. http://dx.doi.org/10.3846/16111699.2012.721392

Aghdaie, M. H.; Hashemkhani Zolfani, S.; Zavadskas, E. K. 2012. Prioritizing constructing projects of municipalities based on AHP and COPRAS-G: a case study about footbridges in Iran, Baltic Journal of Road and Bridge Engineering 7(2): 145-153. http://dx.doi.org/10.3846/bjrbe.2012.20

Alvarez, I.; Marin, R. 2013. FDI and technology as levering factors of competitiveness in developing countries, Journal of International Management 19(3): 232-246.

http://dx.doi.org/10.1016/j.intman.2013.02.005

Athreye, S.; Keeble, D. 2000. Technological convergence, globalisation and ownership in the UK computer industry, Technovation 20(5): 227-245. http://dx.doi.org/10.1016/S0166-4972(99)00135-2

Ba, X.; Zhang, Y.; Wu, Y. N. 2011. An AHP grey evaluation model of the real estate investment risk, Computing and Intelligent Systems 234: 325-334. http://dx.doi.org/10.1007/978-3-642-24091-1_43

Baron, R. A.; Markman, G. D. 2003. Beyond social capital: the role of entrepreneurs' social competence in their financial success, Journal of Business Venturing 18(1): 41-60. http://dx.doi.org/10.1016/S0883-9026(00)00069-0

Bashir, R. 2004. BioMEMS: state-of-the-art in detection, opportunities and prospects, Advanced Drug Delivery Reviews 56(11): 1565-1586. http://dx.doi.org/10.1016/j.addr.2004.03.002

Bayraktar, E.; Young, V. R. 2010. Optimal investment strategy to minimize occupation time, Annals of Operations Research 176(1): 389-408. http://dx.doi.org/10.1007/s10479-008-0467-2

Bitarafan, M.; Hashemkhani Zolfani, S.; Arefi, S. L.; Zavadskas, E. K. 2012. Evaluating the construction methods of cold-formed steel structures in reconstructing the areas damaged in natural crises, using the methods AHP and COPRAS-G, Archives of Civil and Mechanical Engineering (12): 360-367.

Benou, G.; Madura, J. 2005. High-tech acquisitions, firm specific characteristics and the role of investment bank advisors, Journal of High Technology Management Research 16(1): 101-120. http://dx.doi.org/10.1016/j.hitech.2005.06.006

Better, M.; Glover, F.; Kochenberger, G.; Wang, H. 2008. Simulation optimization: applications in riskmanagement, International Journal of Information Technology \& Decision Making 7(4): 571-587. http://dx.doi.org/10.1142/S0219622008003137

Boguslauskas, V.; Mileris, R.; Adlyte, R. 2011. New internal rating approach for credit risk assessment, Technological and Economic Development of Economy 17(2): 369-381.

http://dx.doi.org/10.3846/20294913.2011.583721 
Boholm, A. 2011. Nanotechnology, risk and communication, Journal of Risk Research 14(10): 1263-1265. http://dx.doi.org/10.1080/13669877.2011.619774

Bor, Y. J.; Chuang, Y. C.; Lai, W. W.; Yang, C. M. 2010. A dynamic general equilibrium model for public R\&D investment in Taiwan, Economic Modelling 27(1): 171-183.

http://dx.doi.org/10.1016/j.econmod.2009.08.007

Chu, C. H.; Luh, Y. P.; Li, T. Z.; Chen, H. 2009. Economical green product design based on simplified computer-aided product structure variation, Computers in Industry 60(7): 485-500. http://dx.doi.org/10.1016/j.compind.2009.02.003

Chung, W.; Talluri, S.; Narasimhan, R. 2011. Price markdown scheme in a multi-echelon supply chain in a high-tech industry, European Journal of Operational Research 215(13): 581-589. http://dx.doi.org/10.1016/j.ejor.2011.07.002

Chorev, S.; Anderson, A. R. 2006. Success in Israeli high-tech start-ups; Critical factors and process, Technovation 26(2): 162-174. http://dx.doi.org/10.1016/j.technovation.2005.06.014

Dulluri, S.; Raghavan, N. R. S. 2008. Collaboration in tool development and capacity investments in high technology manufacturing networks, European Journal of Operational Research 187(3): 962-977. http://dx.doi.org/10.1016/j.ejor.2006.06.059

Ernst, D. 2005. Pathways to innovation in Asia's leading electronics-exporting countries - a framework for exploring drivers and policy implications, International Journal of Technology Management 29(1-2): 6-20. http://dx.doi.org/10.1504/IJTM.2005.006002

Ernst, D.; Naughton, B. 2005. China's emerging industrial economy insights from the IT Industry, paper prepared for the East-West Center Conferenceon China's Emerging Capitalist System, August 10-12, 2005, Honolulu, Hawaii [online], [cited 3 February 2013]. Available from Internet: http://www. eastwestcenter.org/fileadmin/stored/misc/Chinas Emerging.pdf

European Commission 2002. Life sciences and biotechnology: a strategy for Europe [online], [cited 3 February 2013]. Available from Internet: http://europa.eu.int

Ferrari, M. 2004. Biomedical nanotechnology, Vol. I-IV. Kluwer Academic Publishers, 202-223.

Fouladgar, M. M.; Yazdani Chamzini, A.; Lashgari, A.; Zavadskas, E. K.; Turskis, Z. 2012. Maintenance strategy selection using AHP and COPRAS under fuzzy environment, International Journal of Strategic Property Management 16(1): 85-104. http://dx.doi.org/10.3846/1648715X.2012.666657

Gao, Y.; Zhang, G. Q.; Lu, J.; Dillon, T.; Zeng, X. Y. 2008. A $\lambda$-cut approximate algorithm for goal-based bilevel risk management systems, International Journal of Information Technology \& Decision Making 7(4): 589-610. http://dx.doi.org/10.1142/S0219622008003113

Ghazinoory, S. 2005. Cleaner production in Iran: necessities and priorities, Journal of Cleaner Production 13(8): 755-762. http://dx.doi.org/10.1016/j.jclepro.2004.01.010

Ghazinoory, S.; Farazkish, M. 2010. A model of technology strategy development for Iranian nano-composite companies, Technological and Economic Development of Economy 16(1): 25-42. http://dx.doi.org/10.3846/tede.2010.02

Ghazinoory, S.; Ghazinoori, S. 2006. Developing government strategies for strengthening national system of innovation, using SWOT analysis: the case of Iran, Science and Public Policy 33(7): 529-549. http://dx.doi.org/10.3152/147154306781778759

Ghazinoory, S.; Ghazinouri, R. 2009. Nanotechnology and sociopolitical modernity in developing countries: case study of Iran, Technological and Economic Development of Economy 15(3): 395-417. http://dx.doi.org/10.3846/1392-8619.2009.15.395-417

Ghazinoory, S.; Huisingh, D. 2006. National program for cleaner production (CP) in Iran: a framework and draft, Journal of Cleaner Production 14(2): 194-200. http://dx.doi.org/10.1016/j.jclepro.2004.11.002

Ginevicius, R. 2011. A new determining method for the criteria weights in multi-criteria evaluation, International Journal of Information Technology \& Decision Making 10(6): 1067-1095.

http://dx.doi.org/10.1142/S0219622011004713 
Godin, B. 2004. The obsession for competitiveness and its impact on statistics: the construction of high-technology indicators, Research Policy 33(8): 1217-1229.

http://dx.doi.org/10.1016/j.respol.2004.07.005

Harbi, S.; Amamou, M.; Anderson, A. R. 2009. Establishing high-tech industry: the Tunisian ICT experience, Technovation 29(6-7): 465-480. http://dx.doi.org/10.1016/j.technovation.2008.11.001

Hashemkhani Zolfani, S.; Rezaeiniya, N.; Aghdaie, M. H.; Zavadskas, E. K. 2012b. Quality control manager selection based on AHP- COPRAS-G methods: a case in Iran, Economska Istrazivanja - Economic Research 25(1): 88-104.

Hashemkhani Zolfani, S.; Chen, I. S.; Rezaeiniya, N.; Tamosaitiene, J. 2012a. A hybrid MCDM model encompassing AHP and COPRAS-G method for the selection of company supplier: a case in Iran, Technological and Economic Development of Economy 18(3): 529-543.

http://dx.doi.org/10.3846/20294913.2012.709472

Hashemkhani Zolfani, S.; Zavadskas, E. K.; Turskis, Z. 2013a. Design of products with both international and local perspectives based on Yin-Yang balance theory and SWARA method, Economska Istrazivanja - Economic Research 26(1): 153-166.

Hashemkhani Zolfani, S.; Esfahani, M. H.; Bitarafan, M.; Zavadskas, E. K.; Lale Arefi, S. 2013b. Developing a new hybrid MCDM method for selection of the optimal alternative of mechanical longitudinal ventilation of tunnel pollutants during automobile accidents, Transport 28(1): 89-96. http://dx.doi.org/10.3846/16484142.2013.782567

Hashemkhani Zolfani, S.; Aghdaie, M. H.; Derakhti, A.; Zavadskas, E. K.; Morshed Varzandeh, M. H. 2013c. Decision making on business issues with foresight perspective; an application of new hybrid MCDM model in shopping mall locating, Expert Systems with Applications 40(17): 7111-7121. http://dx.doi.org/10.1016/j.eswa.2013.06.040

Hashemkhani Zolfani, S.; Zavadskas, E. K. 2013. Sustainable development of rural areas' building structures based on local climate, Procedia Engineering 57: 1295-1301.

http://dx.doi.org/10.1016/j.proeng.2013.04.163

Hemmert, M. 2004. The influence of institutional factors on the technology acquisition performance of high-tech firms: survey results from Germany and Japan, Research Policy 33(6-7): 1019-1039. http://dx.doi.org/10.1016/j.respol.2004.04.003

$\mathrm{Hu}$, Q.; Quan, J. J. 2005. Evaluating the impact of IT investments on productivity: a causal analysis at industry level, International Journal of Information Management 25(1): 39-53.

http://dx.doi.org/10.1016/j.ijinfomgt.2004.10.006

Hurmelinna, P.; Peltola, S.; Tuimala, J.; Virolainen, V. M. 2002. Attaining world-class R\&D by benchmarking buyer-supplier relationships, International Journal of Production Economics 80(1): 39-47. http://dx.doi.org/10.1016/S0925-5273(02)00241-4

Kenney, M.; Breznitz, D.; Murphree, M. 2013. Coming back home after the sun rises: returnee entrepreneurs and growth of high tech industries, Research Policy 42(2): 391-407.

http://dx.doi.org/10.1016/j.respol.2012.08.001

Kent, D. M. 1992. A framework for integrated risk management in international business, Journal of International Business Studies 23(2): 311-331. http://dx.doi.org/10.1057/palgrave.jibs. 8490270

Keršulienė, V.; Turskis, Z. 2011. Integrated fuzzy multiple criteria decision making model for architectselection, Technological and Economic Development of Economy 17(4): 645-666. http://dx.doi.org/10.3846/20294913.2011.635718

Keršulienė, V.; Zavadskas, E. K.; Turskis, Z. 2010. Selection of rational dispute resolution method by applying new step-wise weight assessment ratio analysis (SWARA), Journal of Business Economics and Management 11(2): 243-258. http://dx.doi.org/10.3846/jbem.2010.12 
Kikuchi, M. 2007. Status and future prospects of biomedical engineering: a Japanese perspective [online], Biomedical Imaging and Intervention Journal 3(3): 1-6, [cited 3 February 2013]. Available from Internet: http://www.biij.org/2007/3/e37

Kulviwat, S.; Bruner II, G. C.; Al-Shuridah, O. 2009. The role of social influence on adoption of high tech innovations: the moderating effect of public/private consumption, Journal of Business Research 62(7): 706-712. http://dx.doi.org/10.1016/j.jbusres.2007.04.014

Lai, Y. B. 2010. The political economy of capital market integration and tax competition, European Journal of Political Economy 26(4): 475-487. http://dx.doi.org/10.1016/j.ejpoleco.2010.02.001

Law, K. M. Y.; Gunasekaran, A. 2012. Sustainability development in high-tech manufacturing firms in Hong Kong: motivators and readiness, International Journal of Production Economics 137(1): 116-125. http://dx.doi.org/10.1016/j.ijpe.2012.01.022

Lee, A. H. I.; Kang, H. Y.; Hsu, C. F.; Hung, H. C. 2009a. A green supplier selection model for high-tech industry, Expert Systems with Applications 36(4): 7917-7927.

http://dx.doi.org/10.1016/j.eswa.2008.11.052

Lee, A. H. L.; Chang, H. J.; Lin, C. Y. 2009b. An evaluation model of buyer-supplier relationships in high-tech industry - the case of an electronic components manufacturer in Taiwan, Computers \& Industrial Engineering 57(4): 1417-1430. http://dx.doi.org/10.1016/j.cie.2009.07.012

Li, H.; Ma, L. 2008. Ranking decision alternatives by integrated DEA, AHP and gower plot techniques, International Journal of Information Technology \& Decision Making 7(2): 241-258. http://dx.doi.org/10.1142/S0219622008002922

Liaudanskienė, R.; Varnas, N.; Ustinovichius, L. 2010. Modeling the application of workplace safety andhealth act in Lithuanian construction sector, Technological and Economic Development of Economy 16(2): 233-253. http://dx.doi.org/10.3846/tede.2010.15

Lin, B. W.; Li, P. C.; Chen, J. S. 2006. Social capital, capabilities, and entrepreneurial strategies: a study of Taiwanese high-tech new ventures, Technological Forecasting \& Social Change 73(2): 168-181. http://dx.doi.org/10.1016/j.techfore.2004.12.001

Liu, C. Y. 1993. Government's role in developing a high tech industry: the case of Taiwan's semiconductor industry, Technovation 13(5): 299-309. http://dx.doi.org/10.1016/0166-4972(93)90003-E

Mäkipelto, T. 2009. Competitive priorities of investment strategy: case wind power, International Journal of Sustainable Economy 1(4): 388-402. http://dx.doi.org/10.1504/IJSE.2009.024764

Mäkipelto, T. 2010a. The competitive priorities of the wind power investment, International Journal of Management and Enterprise Development 9(3): 292-310. http://dx.doi.org/10.1504/IJMED.2010.037068

Mäkipelto, T. 2010b. The competitive priorities affecting energy production investments: $\mathrm{PhD}$ thesis of Industrial Management, Acta Wasaensia No. 231, Universitas Wasaensis.

Mäkipelto, T.; Takala, J. 2009. The model based on the analytic hierarchy process fordynamic decision making in the energy industry: a case analysis of investmentenergy production in Finland, International Journal of Nuclear Governance, Economy and Ecology 2(3): 281-295. http://dx.doi.org/10.1504/IJNGEE.2009.026517

Mamuneas, T. P. 1999. Spillovers from publicly financed R\&D capital in high-tech industries, International Journal of Industrial Organization 17(2): 215-239. http://dx.doi.org/10.1016/S0167-7187(97)00039-8

Mendonca, S. 2009. Brave old world: accounting for 'high-tech' knowledge in 'low-tech' industries, Research Policy 38(3): 470-482. http://dx.doi.org/10.1016/j.respol.2008.10.018

Metrick, A. 1999. Performance evaluation with transactions data: the stock selection of investmentnewsletters, The Journal of Finance 54(5): 1743-1775. http://dx.doi.org/10.1111/0022-1082.00165

Naschie, M. S. E. 2006. Nanotechnology for the developing world, Chaos, Solitons \& Fractals Journal 30(4): 769-773. http://dx.doi.org/10.1016/j.chaos.2006.04.037 
Ouyang, H. S. 2006. Agency problem, institutions, and technology policy: explaining Taiwan's semiconductor industry development, Research Policy 35(9): 1314-1328.

http://dx.doi.org/10.1016/j.respol.2006.04.013

Peng, Y.; Kou, G.; Wang, G. X.; Wang, H. G.; Ko, F. I. S. 2009. Empirical evaluation of classifiers for softwarerisk management, International Journal of Information Technology \& Decision Making 8(4): 749-767. http://dx.doi.org/10.1142/S0219622009003715

Peng, Y.; Wang, G.; Kou, G.; Shi, Y. 2010. An empirical study of classification algorithm evaluation infinancial risk management, Applied Soft Computing 11(2): 2906-2915. http://dx.doi.org/10.1016/j.asoc.2010.11.028

Petersen, K. E. 1982. Silicon as a mechanical material, in Proc. of IEEE 70(5): 420-457. http://dx.doi.org/10.1109/PROC.1982.12331

Praset, M. 1998. Changing technological capabilities in high-tech firms: a study of the telecommunications industry, The Journal of High Technology Management Research 9(2): 175-193.

http://dx.doi.org/10.1016/S1047-8310(98)90003-7

Rezaeiniya, N.; Hashemkhani Zolfani, S.; Zavadskas, E. K. 2012. Greenhouse locating based on ANPCOPRAS-G methods - an empirical study based on Iran, International Journal of Strategic Property Management 16(2): 188-200. http://dx.doi.org/10.3846/1648715X.2012.686459

Rosa, P. A. J.; Azevedo, A. M.; Sommerfeld, S.; Backer, W.; Aires-Barros, M. R. 2011. Aqueous two-phase extraction as a platform in the biomanufacturing industry: economical and environmental sustainability, Biotechnology Advances 29(6): 559-567. http://dx.doi.org/10.1016/j.biotechadv.2011.03.006

Ruyter, K.; Moorman, L.; Lemmink, J. 2001. Commitment and trust in customer-supplier relationships in high technology markets, Industrial Marketing Management 30(3): 271-286.

http://dx.doi.org/10.1016/S0019-8501(99)00091-7

Saaty, L. T. 1980. The analytic hierarchy process. New York: McGraw Hill Company. 287 p.

Saaty, L. T.; Vargas, L. G. 2001. Models, methods, concepts \& applications of the analytical hierarchy process. Boston: Kluwer Academic Publishers. 333 p. http://dx.doi.org/10.1007/978-1-4615-1665-1

Seo, J. K. 2013. Gwangju: a hub city of Asian culture and high-tech industry, Cities 31: 563-577. http://dx.doi.org/10.1016/j.cities.2012.05.001

Shannon, C. E. 1948. The mathematical theory of communication, Bell System Technical Journal 27(4): 379-423. http://dx.doi.org/10.1002/j.1538-7305.1948.tb00917.x

Shen, C. 2009. A bayesian networks approach to modeling financial risks of E-Logistics investments, International Journal of Information Technology \& Decision Making 8(4): 711-726. http://dx.doi.org/10.1142/S0219622009003594

Shyng, J.; Shieh, H.; Tzeng, G.; Hsieh, S. 2010. Using FSBT technique with rough set theory for personalinvestment portfolio analysis, European Journal of Operational Research 201(2): 601-607. http://dx.doi.org/10.1016/j.ejor.2009.03.031

Staggers, N.; McCasky, T.; Brazelton, N.; Kennedy, R. 2008. Nanotechnology: the coming revolutionand its implications for consumers, clinicians, and informatics, Nursing Outlook 56(5): 268-274. http://dx.doi.org/10.1016/j.outlook.2008.06.004

Sušinskas, S.; Zavadskas, E. K.; Turskis, Z. 2011. Multiple criteria assessment of pile-columns alternatives, Baltic Journal of Road and Bridge Engineering 6(3): 77-83. http://dx.doi.org/10.3846/bjrbe.2011.19

Temouri, Y.; Driffield, N. A.; Higon, D. A. 2010. The futures of offshoring FDI in high-tech sectors, Futures 42(9): 960-970. http://dx.doi.org/10.1016/j.futures.2010.08.024

Tsai, K. H. 2004. The impact of technological capability on firm performance in Taiwan's electronics industry, Journal of High Technology Management Research 15(2): 183-195.

http://dx.doi.org/10.1016/j.hitech.2004.03.002 
Tsai, Y.; Lin, J. F.; Kurekova, L. 2009. Innovative R\&D and optimal investment under uncertainty in high-techindustries: an implication for emerging economies, Research Policy 38(8): 1388-1395. http://dx.doi.org/10.1016/j.respol.2009.06.006

Tzafrir, S. S.; Eitam-Meilik, M. 2005. The impact of downsizing on trust and employee practices in high tech firms: a longitudinal analysis, Journal of High Technology Management Research 16(2): 193-207. http://dx.doi.org/10.1016/j.hitech.2005.10.008

Wang, D. H. M. 2010. Corporate investment, financing, and dividend policies in the high-tech industry, Journal of Business Research 63(5): 486-489. http://dx.doi.org/10.1016/j.jbusres.2009.04.006

Wise, K. D.; Najafi, K. 1991. Micro-fabrication techniques for integrated sensors and microsystems, Science 254(5036): 1335-1342. http://dx.doi.org/10.1126/science.1962192

Wu, I. L.; Chen, J. L. 2006. A hybrid performance measure system for e-business investments in high-tech manufacturing: an empirical study, Information \& Management 43(3): 364-377. http://dx.doi.org/10.1016/j.im.2005.08.007

Wu, W.; Kou, G.; Peng, Y.; Ergu, D. 2012. Improved AHP-group decision making for investment strategy selection, Technological and Economic Development of Economy 18(2): 299-316. http://dx.doi.org/10.3846/20294913.2012.680520

Zavadskas, E. K.; Turskis, Z.; Tamošaitiene, J. 2010. Risk assessment of construction projects, Journal of Civil Engineering and Management 16(1): 33-46. http://dx.doi.org/10.3846/jcem.2010.03

Zavadskas, E. K.; Kaklauskas, A. 1996. Determination of an efficient contractor by using the new method of multi criteria assessment, in Langford, D. A.; Retik, A. (Eds.). International Symposium for "The Organization and Management of Construction". Shaping Theory and Practice. Vol. 2: Managing the Construction Project and Managing Risk. CIB W 65; London, Weinheim, New York, Tokyo, Melbourne, Madras. London: E and FN SPON, 94-104.

Zhang, M.; He, Y.; Zhou, Z. F. 2013. Study on the influence factors of high-tech enterprise credit risk: empirical evidence from China’s listed companies, Procedia Computer Science 17: 901-910. http://dx.doi.org/10.1016/j.procs.2013.05.115

Zolfani, S. H.; Farrokhzad, M.; Turskis, Z. 2013. Investigating on successful factors of online games based on explorer, E \& M Ekonomie a Management 16(2): 161-169.

Zolfani, S. H.; Rezaeiniya, N.; Zavadskas, E. K.; Turskis, Z. 2011. Forest roads locating based on AHP-PRAS-G methods - an empirical study based on Iran, E\& M Ekonomie a Management 14(4): 6-21.

Sarfaraz HASHEMKHANI ZOLFANI received his BSc in Industrial Management and MSc in Industrial Engineering from Shomal University, Iran. He is a PhD student of Technology Foresight in Amirkabir University of Technology (Tehran Polytechnic). He is working at Futures Studies Research Institute of Amirkabir University of Technology (Tehran Polytechnic), Sustainability office of Amirkabir University of Technology (Tehran Polytechnic) and Research Institute of the Internet and Intelligent Technologies, Vilnius Gediminas Technical University. He is a member of EURO Working Group OR in Sustainable Development and Civil Engineering. He is a reviewer in journals like: International Journal of Strategic Property Management, International Journal of Business and Society, etc. He is author of more than 45 scientific papers that presented, published or reviewed at/for International Conferences and Journals (including ISI-cited publications). He has published in journals such as: Expert Systems With Applications, Technological and Economic Development of Economy, Journal of Business Economics and Management, International Journal of Strategic Property Management, Archives of Civil and Mechanical Engineering, Transport, The Baltic Journal of Road and Bridge Engineering etc. His research interests include: performance evaluation, strategic management, decision-making theory, supply chain management, (fuzzy) multi criteria decision making, marketing, future studies and sustainable development. 
Mohsen BAHRAMI is heading the Technology Foresight group at the Department of Management, Science and Technology. He is also a faculty member (Professor) of Mechanical Engineering Department, Amirkabir University of Technology, Tehran, Iran. He is a Chair of the Iran Node of The Millennium Project, has been a founding Director of the Aerospace Research Institute Ministry of Science, Research and Technology, and of the New Technologies Research Center, and the Futures Studies Research Center at the Amirkabir University of Technology; Director of the Office of Research Affairs, Ministry of Higher Education; and also held different executive and technical positions such as: Head, New Technologies Committee, National Research Council; Research Advisor to the General Director of Civil Aviation Organization; and funding Coordinator of Robotics and Automation, Amirkabir University of Technology. He has over 25 publications, more than 300 journal and conference papers, and has lectured and given talks in different areas of future studies. 